\title{
Penerapan E-learning pada Pendidikan Anak Usia Dini di Masa Pendemi Covid-19
}

\author{
Cindy Tri Kusumawardani ${ }^{{ }_{1}}{ }$ Dimyati $^{2}$ \\ Pendidikan Anak Usia Dini, Universitas Negeri Yogyakarta, Indonesia(1) \\ Pendidikan Olahraga, Universitas Negeri Yogyakarta, Indonesia(2) \\ DOI: $\underline{10.31004 / \text { obsesi.v6i2.1002 }}$
}

\begin{abstract}
Abstrak
Epidemi COVID-19 telah menyebar ke seluruh dunia. Hal ini berdampak pada semua aspek kehidupan manusia. Salah satu aspek yang terpengaruh adalah dunia pendidikan. Pendidikan Indonesia yang masih menggunakan sistem tradisional telah beralih menggunakan e-learning. Oleh karena itu, penelitian ini bertujuan untuk mendeskripsikan secara mendalam mengenai penerapan e-learning pada anak usia dini di masa pandemi. Pendekatan yang digunakan dalam penelitian ini yaitu kualitatif dengan jenis penelitian kepustakaan. Penelitian ini menggunakan sumber pustaka yaitu menggunakan artikel jurnal dan buku. Hasil penelitian menunjukkan bahwa e-learning dapat diterapkan pada PAUD meskipun belum maksimal. Hal ini dikarenakan terdapat berbagai macam hambatan ketika melaksanakan proses pembelajaran. Pembelajaran dilakukan menggunakan aplikasi whatsapp, youtube, instagram, googleclass, dan instagram. Selain itu, penerapan e-learning memberikan dampak pada pencapaian perkembangan anak. Sebagian besar dari aspek perkembangan anak mengalami penurunan kecuali aspek seni. Saran untuk peneliti selanjutnya yang membahas e-learning pada anak usia dini agar melakukan penelitian yang dilakukan secara lebih mendalam.
\end{abstract}

Kata Kunci: e-learning; pendidikan anak usia dini; masa pendemi covid-19

\begin{abstract}
The COVID-19 epidemic has spread across the world. This affects all aspects of human life. One aspect that is affected is the world of education. Indonesian education, which still uses the traditional system, has switched to using e-learning. Therefore, this study aims to describe in depth the application of e-learning to early childhood during the pandemic. The approach used in this research is qualitative with the type of library research. This study uses library sources, namely using journal articles and books. The results showed that e-learning can be applied to PAUD even though it is not optimal. This is because there are various kinds of obstacles when carrying out the learning process. The learning is carried out using the WhatsApp, YouTube, Instagram, Googleclass, and Instagram applications. In addition, the application of e-learning has an impact on the achievement of children's development. Most of the aspects of child development have decreased, except for the artistic aspect. Suggestions for the next researcher who discusses e-learning in early childhood are to carry out research conducted in more depth.
\end{abstract}

Keywords: e-learning; early ehildhood education; pandemic time covid-19

Copyright (c) 2021 Cindy Tri Kusumawardani, Dimyati

$\bowtie$ Corresponding author:

Email Address : cindytrikusumawardani@gmail.com (Yogyakarta, Indonesia)

Received 24 December 2020, Accepted 5 January 2021, Published 20 June 2021

622 | Jurnal Obsesi: Jurnal Pendidikan Anak Usia Dini, 6(2), 2022 


\section{PENDAHULUAN}

Akhir tahun 2019, dunia digemparkan dengan munculnya sebuah penyakit yang dapat menyebabkan kematian mendadak. Kota Wuhan, Cina menjadi tempat pertama kali ditemukan penyakut tesebut. Hal ini diperjelas dengan pemerintahan Cina memberikan pengumuman bahwa terdapat warganya yang tewas karena menderita pneumonia yang disebabkan virus corona (Febrian, 2020). Istilah dari penyakit tersebut adalah COVID-19 (penyakit virus corona). World Helath Organization (WHO) menjelaskan bahwa COVID-19 merupakan penyakit menular yang menyerang saluran pernafasan manusia.

Virus ini menjadi perhatian bagi seluruh warga dunia. Hal ini disebabkan virus COVID-19 menyebar dengan cepat, dan belum adanya vaksin untuk mencegah penyebaran virus ini. COVID-19 cepat menyebar karena dapat menular dari satu individu yang terinfeksi ke orang ya sehat (Susilo et al., 2020). Penularannya dapat melalui kontak langsung maupun menyentuh permukaan yang terkontaminasi dengan virus tersebut.

Berkembang pesatnya penyakit ini membuat virus COVID-19 menyebar di seluruh dunia. Sesuai dengan hal tersebut seluruh dunia sedang terkena musibah karena penyebaran virus ini. Negara Indonesia juga menjadi salah satu Negara yang terkena penyebaran virus COVID-19. Penyebaran virus COVID-19 mulai masuk ke Indonesia sejak awal Januari. Namun, pemerintah Indonesia pertama kali mengumumkan pasien positif COVID-19 pada 2 Maret 2020 (Pranita, 2020). Pengumuman ini menjadi perhatian bagi warga Indonesia.

Pemerintah juga bekerja dengan cepat untuk mencegah penyebaran virus COVID-19. Meskipun pemerintah sudah berupaya dengan cepat, penyebaran virus ini mulai tidak bisa dikendalikan karena mobilitas dari warga Indonesia. Oleh sebab itu, pemerintah membuat kebijakan untuk mengatur warganya supaya tidak melakukan perkumpulan warga dengan mengundang banyak orang (Kepolisian Republik Indonesia, 2020).

Kebijakan yang diambil pemerintah ini memberikan dampak bagi seluruh sektor kehidupan manusia. Salah satu yang terdampak dengan kebijakan ini adalah dunia pendidikan. Adanya wabah ini tidak mungkin pendidikan yang ada di Indonesia berhenti secara total. Pendidikan harus tetap berjalan sebagaimana mana mestinya. Sesuai dengan Undang-Undang Dasar Pasal 31 Ayat 1 yang menjelaskan bahwa tiap-tiap warga negara berhak mendapat pengajaran (Undang-Undang Dasar Negera Republik Indonesia 1945, n.d.).

Pemerintah secara sigap untuk menangani masalah ini dengan membuat sebuah kebijakan baru. Berdasarkan Surat Edaran Mendikbud Nomor 4 Tahun 2020 menetapkan kebijakan untuk SFH (School From Home) atau melakukan pembelajaran e-learning (Surat Edaran Nomor 4 Tahun $2 \mathrm{O} 2 \mathrm{O}$ Tentang Pelaksanaan Kebijakan Pendidikan Dalam Masa Darurat Penyebaran Corona Virus Disease (COVID- 19), 2020)(Surat Edaran Nomor 4 Tahun $2 \mathrm{O} 2 \mathrm{O}$ Tentang Pelaksanaan Kebijakan Pendidikan Dalam Masa Darurat Penyebaran Corona Virus Disease (COVID- 19), 2020). Kebijakan yang dibuat berlaku baik untuk jenjang perguruan tinggi hingga pendidikan anak usia dini.

Pendidikan usia dini merupakan pendidikan yang diberikan dari sejak lahir hingga berusia 6 tahun (Depdiknas, 2003). Pendidikan yang diterapkan yaitu dengan memberikan rangsangan di setiap aspek perkembangan anak. Aspek perkembangan tersebut meliputi fisik motoric, kognitif, sosial emosional, bahasa, seni, dan agama moral (Mendikbud, 2020). Sesuai dengan kebijakan yang ada pemberian rangsangan pada aspek perkembangan anak melalui e-learning.

E-learning adalah suatu pembelajaran yang memanfaat internet (Harsasi, 2015; 77; Junus et al., 2015: 64; Wahyuningsih \& Makmur, 2017: 3). Penggunaan e-learning memudahkan bagi pendidik dan peserta didik untuk mengaksesnya dapat dilakukan di mana saja maupun kapan saja (Suartama, 2014: 28). Pembelajaran yang dilakukan tidak secara langsung ketika di dalam kelas.

E-learning ini menggunakan platform pengajaran yang bergantung pada teknologi bukan lagi menggunakan kertas dan ruang kelas (Alqudah et al., 2020: 44). E-learning harus menggunakan alat untuk mendukung proses pembelajaran (Kumar Basak et al., 2018: 194). 
Alat yang dapat digunakan untuk memudahkan e-learning adalah computer, laptop, CDROM, DVD, tab, televise, maupun ponsel android (Adnan, 2019: 138; Aparicio et al., 2016: 295; Harsasi, 2015: 77; Kumar Basak et al., 2018: 202; Nurdyansah \& Fahyuni, 2016: 119).

Sebelum adanya pendemi COVID ini telah dikembangkan e-learning untuk anak usia dini. Sebuah penelitian menunjukkan bahwa telah dikembangkan sebuah aplikasi untuk mendukung e-learning mengenai alat transportasi dengan bahasa inggris pada anak usia dini berbasis android. Pengembangan aplikasi ini dapat digunakan sebagai terobosan bagi pendidikan maupun orang tua untuk membantu proses dalam pembelajaran (Yundatama \& Parno, 2015: 134).

Sistem e-learning ini sama dengan pembelajaran offline ketika di dalam kelas. E-learning juga memberikan materi atau penjelasan mengenai tema pembelajaran pada saat itu. Pemberian materi yang dapat melalui audio, video, dan media teks (Al-Fraihat et al., 2020: 68). Variasi berbagai macam pemberian materi secara instruksional membuat e-learning menjadi menarik.

Pelaksanaan peraturan yang ditetapkan oleh Menteri Pendidikan Indonesia tidak mudah. Meskipun pada Bulan Januari 2020 sebanyak 175, 4 (64\%) juta warga Indonesia telah menggunakan internet (Kemp, 2020). Usia yang paling banyak yang menggunakan internet yaitu 15-19 tahun (Qwords, 2019). Padahal usia pendidik di lembaga anak usia dini sudah lebih dari itu. Hal yang ini menyebabkan pendidik tidak mahir dalam mengoperasikan media digital.

Pendidik yang tidak mahir menggunakan media digital ini disebabkan oleh beberapa faktor. Sebuah penelitian menjelaskan bahwa kendala yang dialami pendidik yaitu kurangnya pengetahuan guru mengenai teknologi informasi berupa laptop/komputer, infokus, printer, dan internet yang disebabkan oleh faktor usia dan kesulitan dalam mencari file, arus listrik di sekolah tidak normal serta internet tidak dapat menjangkau ke semua gedung sekolah, dan sekolah tidak diwajibkan bagi guru mengajar dengan menggunakan media teknologi informasi (Sahelatua et al., 2017: 138). Kendala yang dialami ini membuat guru belum siap untuk melaksanakan e-learning pada saat adanya wabah ini. Lebih dari peran orang tua juga menentukan keberhasilan pembelajan pada anak, orang tua dituntut untum memiliki kemampuan yang setara dengan guru di sekolah (Fauziddin et al., 2021)

Berdasarkan uraian latar belakang di atas, maka dapat dirumuskan masalah dari penelitian ini adalah bagaimana penerapan e-learning pada anak usia dini di masa pendemi COVID-19. Mengacu pada rumusan masalah maka tujuan dari penulisan ini yaitu mendeskripsikan secara mendalam mengenai penerapan e-learning pada anak usia dini di masa pendemi.

\section{METODOLOGI}

Pendekatan yang digunakan pada penelitian ini adalah pendekatan kualitatif deskriptif dengan jenis penelitian kepustakaan (library research). Library research merupakan metode pengumpulan data pustaka, membaca, dan mengolah bahan penelitian (Zed, 2008:3). Sumber acuan kepustakaan yang dapat digunakan dalam penelitian beragam yaitu buku teks, artikel jurnal, periodical, yearbook, bulletin, annual review, recent advance, bibliografi, handbook, dan manual (Anshori \& Iswati, 2009: 38-41). Penelitian ini menggunakan sumber kepustakaannya yaitu artikel jurnal dan buku. Analisis data kualitatif digunakan sebagai teknik analisis data pada penelitian ini. Hal ini dilakukan supaya dapat menjabarkannya secara mendalam. Secara rinci langkah-langkah yang digunakan dalam penelitian ini sebagaimana pada gambar 1. 
DOI: 10.31004/obsesi.v6i2.1002

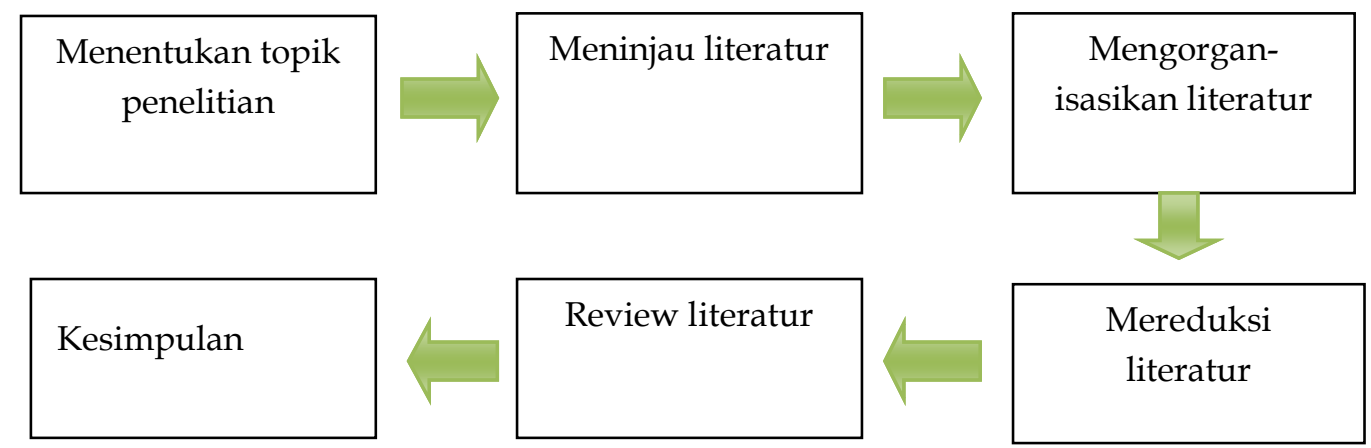

Gambar 1. Langkah-langkah Penelitian

\section{HASIL DAN PEMBAHASAN}

Pemilihan data penelitian dilakukan melalui database yang ada di beragam jurnal. Jurnal yang digunakan terdiri dari Jurnal Obsesi, Thufuli: Jurnal Ilmiah Pendidikan Islam Anak Usia Dini, Intizar: Jurnal Raden Fatah, Scholaria: dan Jurnal Pendidikan dan Kebudayaan. Kata kunci yang digunakan untuk memudahkan pemilihan data yaitu menggunakan beberapa kata kunci yaitu pembelajaran online, pembelajaran daring, dan elearning. Hasil dari pemilihan data menemukan sebelas artikel yang revelan yang berkaitan e-learning pada anak usia dini. Metode yang digunakan pada penelitian tersebut beragam yang meliputi kualitatif, kuantitatif, dan campuran.

E-learning merupakan salah satu trobosan jenis pembelajaran yang tepat untuk digunakan pada saat pendemi. Ini disebabkan e-learning adalah pembelajaran yang menggunakan teknologi dan tidak menggunakan kertas bahkan ruangan untuk mengajar (Alqudah et al., 2020: 1). Adanya teknologi ini membantu guru dan anak untuk tetap melaksanakan pembelajaran meskipun tidak bertemu langsung.

E-learning tidak hanya diterapkan pada perguruan tinggi saja. Akan tetapi merujuk pada Surat Edaran Mendikbud Nomor 4 Tahun 2020 menjelaskan bahwa e-learning juga diterapkan pada anak usia dini (Surat Edaran Nomor 4 Tahun 2O2O Tentang Pelaksanaan Kebijakan Pendidikan Dalam Masa Darurat Penyebaran Corona Virus Disease (COVID- 19), 2020). Tentunya pembelajaran yang dilaksanakan tidak semandiri seperti orang dewasa karena anak masih membutuhkan pendampingan ketika menggunakan teknologi.

Tabel 1 Aplikasi yang digunakan e-learning di PAUD

\begin{tabular}{lll}
\hline Peneliti & Tahun & Aplikasi \\
\hline Ayuni, dkk & 2020 & Whatsapp, Instagram, Youtube \\
Fadillah & 2020 & Whatsapp, Instagram \\
Nurdin \& Muhdi & 2020 & Whatsapp, Googleclass \\
Dina, L. N. A. B & 2020 & $\begin{array}{l}\text { Whatsapp, Amdomo, Instagram, Google meet, } \\
\text { Google classroom }\end{array}$ \\
\hline
\end{tabular}

E-learning yang dilaksanakan pada pendidikan anak usia dini tidak menggunakan web khusus. Akan tetapi, aplikasi yang digunakan aplikasi yang sederhana seperti whatapps, youtube, instagram, googleclass, dan instagram (Atiqoh, 2020: 51; Ayuni et al., 2020: 417-418; Fadlilah, 2020: 477; Nurdin \& Anhusadar, 2020: 690). Pemilihan aplikasi ini guna memudahkan pendidik dan wali murid saat pelaksanaan pembelajaran.

Aplikasi tersebut memiliki fungsi yang berbeda ketika proses pembelajaran. Aplikasi untuk pembelajaran meliputi WAG, instagram, youtube, dan googleclass. Penggunaan aplikasi yang menggunakan video teleconferen supaya terjadinya komunikasi dua arah layaknya ketika berada di sekolah (Peraturan Menteri Komunikasi Dan Informatika Nomor 4 Tahun 2013 Tanggal 14 Januari 2013, 2013; Tafqihan, 2011: 149). Selain itu, penggunaan aplikasi tersebut 
membuat pendidik dapat mengirimkan audio, video, maupun gambar supaya pembelajaran yang berlangsung menjadi menarik (Donnelly et al., 2012: 11).

Aplikasi whatapps dan instagram digunakan untuk melaporkan kegiatan anak ketika di rumah dan sebagai tempat publikasi hasil karya anak. Ketika proses pembelajaran di sekolah hasil karya anak di pajang di kelas tetapi ketika di rumah hasil karya anak dipublikasikan via whatapps dan instagram milik guru kelas (Fadlilah, 2020: 378-379). Publikasi yang dilakukan guru supaya anak tetap termotivasi saat melakukan e-learning dan merupakan bentuk rewad bagi anak. Rewad ini memiliki fungsi untuk meningkatkan motivasi, meningkatkan konsentrasi, dan keaktifan anak (Febianti, 2018: 99).

Proses e-learning pada anak usia dini tidak serta merta dapat dilaksanakan sendiri dengan guru saja. Akan tetapi membutuhkan pedampingan orang tua. Hal ini sesuai dengan tri pusat pendidikan yang mana saling terkait antara rumah, sekolah, dan masyarakat (Siswoyo et al., 2013: 136). Secara rinci peran orang tua dalam e-learning pada anak usia dini.

Tabel 2 Peran orang tua dalam kegiatan e-learning di PAUD

\begin{tabular}{|c|c|c|}
\hline Peneliti & Tahun & Peran Orang Tua \\
\hline Lilawati, A & 2020 & $\begin{array}{ll}\text { - } & \text { Melaksanakan pembelajaran yang telah disusun guru } \\
& \text { sebelumnya } \\
\text { - } & \text { Memberikan motivasi pada anak }\end{array}$ \\
\hline $\begin{array}{l}\text { Kurniati, E., Alfaeni, D. } \\
\text { K. N., \& Andriani, F }\end{array}$ & 2020 & $\begin{array}{l}\text { - Memastikan dan menjaga anak untuk tetap } \\
\text { - Melaksanakan hidup bersih dan sehat } \\
\text { - Mendampingi anak ketika pembelajaran } \\
\text { - Sebagai role model yang baik } \\
\text { - Memberikan motivasi dan membimbing anak } \\
\text { - Memberikan edukasi pada anak }\end{array}$ \\
\hline Zakariyah \& Hamid & 2020 & - Memberikan kontrol atau pengawasan pada anak \\
\hline
\end{tabular}

Tabel 2 menunjukkan bahwa peran orang tua ketika e-learning cukup beragam (Kurniati et al., 2020: 224-252; Lilawati, 2020: 554; Zakariyah \& Hamid, 2020: 22). Peran pertama orang tua yaitu melaksanakan pembelajaran yang telah disusun guru. Ini dilakukan karena tidak semua melakukan video teleconference ketika e-learning yang menyebabkan orang tua masih melaksanakan pembelajaran yang disusun guru. Kedua, tidak hanya melaksanakan pembelajaran orang tua juga memberikan pendidikan bagi anak baik akhlak maupun pengetahuan. Ketiga, seperti istilah guru adalah digugu dan dituru maka orang tua juga harus memberikan role model yang baik bagi anak karena pada usia dini anak masih menjadi peniru yang ulung (Cahyaningrum et al., 2017: 205). Keempat, orang tua harus memberikan motivasi dan bimbingan kepada anak yang tentunya ketika belajar dari rumah memiliki rasa yang berbeda dengan belajar di sekolah. Kelima, orang tua selalu memberikan kontrol pada anak ketika melakukan e-learning yang menggunakan gadget ketika pembelajaran. Ini sebagai upaya agar anak tidak menggunakan gadget secara berlebih dan membuka konten yang sesuai dengan usianya.

Sesuai pernyataan di atas, peran orang tua layaknya guru ketika di sekolah. Peran guru dalam pendidikan anak usia dini yaitu sebagai pembimbing, fasilitator, dan motivator (Maiza \& Nurhafizah, 2019: 361). Tentunya hal ini tidak mudah bagi orang tua. Apalagi jika orang tua tidak memiliki latar belakang sebagai pendidik di lembaga pendidikan. Oleh sebab itu, akan timbul hambatan-hambatan ketika e-learning.

Tabel 3 menjelaskan bahwa adanya hambatan ketika proses e-learning berlangsung. Hambatan yang dialami baik oleh guru maupun orang tua murid (Anugrahana, 2020: 286-287; Ayuni et al., 2020: 414; Nurkholis \& Muhdi, 2020: 223; Wardani \& Ayriza, 2020: 775-779).

Hambatan yang dialami guru meliputi tidak semua guru memiliki media digital untuk e-learning, belum mahirnya guru dalam mengoperasikan aplikasi, dan jaringan internet yang 
belum merata. Sedangkan hambatan yang dialami orang tua antara lain perangkat $e$-learning yang belum memadai, jaringan internet yang belum merata, orang tua yang kurang memahami materi pembelajaran, tidak sabar ketika pelaksanaan pembelajaran, sulitnya orang tua menumbuhkan minat anak, dan tidak ada waktu untuk mendampingi anak ketika $e$ learning. Selain itu, adanya e-learning membuat biaya pendidikan baik bagi guru dan orang tua wali menjadi mahal (Allen, 2013: 134). Hambatan-hambatan tersebut akan mengganggu jalannya pembelajaran.

Tabel 3 Hambatan e-learning di PAUD

\begin{tabular}{|c|c|c|}
\hline Peneliti & Tahun & Hambatan e-learning \\
\hline $\begin{array}{l}\text { Nurkholis \& } \\
\text { Muhdi }\end{array}$ & 2020 & $\begin{array}{l}\text { - Guru yang belum mahir menggunakan aplikasi untuk e-learning } \\
\text { - Guru dan orang tua tidak semua mempunya media digital sebagai } \\
\text { media e-learning }\end{array}$ \\
\hline $\begin{array}{l}\text { Wardani \& } \\
\text { Ayaza }\end{array}$ & 2020 & $\begin{array}{l}\text { - Orang tua kurang memahami materi yang diberikan guru } \\
\text { - Sulit menumbuhkan minat anak } \\
\text { - Tidak mudah untuk mengoperasikan gadget } \\
\text { - Tidak adanya waktu untuk mendampingi e-learning } \\
\text { - Tidak sabar ketika e-learning } \\
\text { - Jaringan internet yang belum merata }\end{array}$ \\
\hline $\begin{array}{l}\text { Ayuni, D., } \\
\text { Marini, T., } \\
\text { Fauziddin, } \\
\text { M., \& } \\
\text { Pahrul, Y }\end{array}$ & 2020 & $\begin{array}{l}\text { - Fasilitas perangkat e-learning yang belum memadai baik dari pihak } \\
\text { guru dan orang tua } \\
\text { - Masih banyak yang beranggapan bahwa e-learning ini sulit } \\
\text { dilaksanakan }\end{array}$ \\
\hline $\begin{array}{l}\text { Anugrahana, } \\
\text { A }\end{array}$ & 2020 & $\begin{array}{l}\text { - } \quad \text { Tidak memiliki perangkat untuk e-learning } \\
\text { - Anak merasa bosan } \\
\text { - } \quad \text { Orang tua sibuk dengan pekerjaan } \\
\text { - Gangguan sinyal }\end{array}$ \\
\hline
\end{tabular}

Proses pembelajaran yang terhambat maka pengetahuan yang didapatkan anak tidak maksimal (Kacetl \& Semradova, 2020: 1326). Begitu pun pada perkembangan anak juga tidak berkembang secara optimal. Berikut hasil perkembangan anak selama masa pendemi.

Tabel 4 Pencapaian perkembangan anak selama e-learning di PAUD

\begin{tabular}{|c|c|c|}
\hline Peneliti & Tahun & Pencapaian Perkembangan Anak \\
\hline $\begin{array}{l}\text { Wulandari, } \\
\text { H. \& } \\
\text { Purwanta, E }\end{array}$ & 2020 & $\begin{array}{l}\text { - Aspek perkembangan anak yang mengalami penurunan yaitu NAM, } \\
\text { fisik motoric, kognitif, sosialemosional, dan bahasa } \\
\text { - Aspek seni pada anak tidak mengalami penurunan }\end{array}$ \\
\hline
\end{tabular}

Secara garis besar tabel 4 menjelaskan bahwa pencapaian perkembangan anak pada elearning mengalami penurunan daripada sebelum terjadi masa pendemi (Wulandari \& Purwanta, 2020: 460). Aspek perkembangan yang mengalami penurunan meliputi aspek nilai agama dan moral, fisik motorik, kognitif, sosialemosional, dan bahasa. Aspek yang cukup drastis mengalami penurunan yaitu pada aspek sosialemosional. Sedangkan, aspek perkembangan anak yang tidak mengalami penurunan yaitu seni.

Sesuai dengan konsep e-learning maka anak banyak berinteraksi dengan media digital yang dapat menyebabkan kecanduan dan berakibat kurangnya interaksi dengan lingkungan sekitar (Imron, 2017: 152). Dampak negative lain penggunaan media digital yang berlebih yaitu keterlambatan bahasa atau berbicara, perhatian yang rendah, masalah belajar, kecemasan, depresi, dan berdampak pada karakter anak (M, 2017: 2). Berdasarkan pemaparan di atas maka penggunan gadget pada anak memberikan dampak pada perkembangan anak. 
Rekomendasi untuk penelitian lain adalah penelitian ini hanya mengungkapkan sebagian kecil dari penerapan e-learning pada anak usia dini. Hal ini disebabkan sumber data penelitian maish sedikit sehingga kurang komplek. Saran untuk peneliti selanjutnya yang membahas ini agar penelitian yang dilakukan secara lebih mendalam.

\section{SIMPULAN}

E-learning dapat diterapkan pada PAUD meskipun belum maksimal. Hal ini disebabkan oleh berbagai macam hambatan ketika melaksanakan proses pembelajaran. Hambatan yang terjadi tidak hanya dirasakan oleh pendidik melainkan orang tua wali murid juga merasakannya. Pembelajaran secara e-learning di PAUD memanfaatkan aplikasi yang terdapat digawai seperti whatsapp, youtube, instagram, googleclass, dan instagram. Pelaksanaanya pun harus didampingi oleh orang tua. Sebab, anak-anak menggunakan media digital ketika proses pembelajaran. Penerapan e-learning memberikan dampak pada pencapaian perkembangan anak. Perkembangan anak mengalami penurunan yaitu pada aspek kognitif, fisik motorik, nilai agama dan moral, sosial emosional. Akan tetapi, aspek perkembangan seni tidak mengalami penurunan.

\section{UCAPAN TERIMA KASIH}

Alhamdulillahirobbil'alamin, rasa syukur ini saya panjatkan kepada Allah SWT yang telah memberikan rahmat dan hidayah-Nya sehingga dapat menyelesaikan penelitian dan menulis karya ilmiah ini. Tentunya penulisan ini tidak dapat diselesaikan tanpa adanya bantuan dari berbagai pihak. Terima kasih kepada para peneliti terkait e-learning pada anak usia dini yang berkontribusi dalam penelitian saya. Dosen mata kuliah yang telah memberikan arahan. Orangtua yang telah memberikan dukungan baik doa, motivasi, dan materi.

\section{DAFTAR PUSTAKA}

Adnan, M., Yousaf, Z., \& Gilani, A. H. (2019). E-Learning with Digital Media and Human Development: The Way Forward for Pakistan. Journal of Educational Research, Dept. of Education, IUB, 22(2), 137-152.

Al-Fraihat, D., Joy, M., Masa'deh, R., \& Sinclair, J. (2020). Evaluating E-learning systems success: An empirical study. Computers in Human Behavior, 102, 67-86. https:// doi.org/10.1016/j.chb.2019.08.004

Allan, B. (2014). The No-nonsense Guide to Training in Libraries. In The No-nonsense Guide to Training in Libraries. Facet Publishing. https://doi.org/10.29085/9781856049634

Alqudah, N. M., Jammal, H. M., Saleh, O., Khader, Y., Obeidat, N., \& Alqudah, J. (2020). Perception and experience of academic Jordanian ophthalmologists with E-Learning for undergraduate course during the COVID-19 pandemic. Annals of Medicine and Surgery, 59(September), 44-47. https://doi.org/10.1016/j.amsu.2020.09.014

Anshori, M., \& Iswati, S. (2009). Metodologi Penelitian Kuantitatif. Airlangga University Press. Anugrahana, A. (2020). Hambatan, Solusi dan Harapan: Pembelajaran Daring Selama Masa Pandemi Covid-19 Oleh Guru Sekolah Dasar. Scholaria: Jurnal Pendidikan Dan Kebudayaan, 10(3), 282-289. https:// doi.org/10.24246/j.js.2020.v10.i3.p282-289

Aparicio, M., Bacao, F., \& Oliveira, T. (2016). An e-Learning Theoretical Framework An eLearning Theoretical Framework. January.

Atiqoh, L. N. (2020). Respon Orang Tua Terhadap Pembelajaran Daring Pada Masa Pandemi Covid-19. Thufuli: Jurnal Ilmiah Pendidikan Islam Anak Usia Dini, 2(1), 45. https:// doi.org/10.33474/thufuli.v2i1.6925

Ayuni, D., Marini, T., Fauziddin, M., \& Pahrul, Y. (2020). Kesiapan Guru TK Menghadapi Pembelajaran Daring Masa Pandemi Covid-19. Jurnal Obsesi : Jurnal Pendidikan Anak Usia Dini, 5(1), 414. https://doi.org/10.31004/obsesi.v5i1.579 
DOI: $10.31004 /$ obsesi.v6i2.1002

Cahyaningrum, E. S., Sudaryanti, S., \& Purwanto, N. A. (2017). Pengembangan Nilai-Nilai Karakter Anak Usia Dini Melalui Pembiasaan Dan Keteladanan. Jurnal Pendidikan Anak, 6(2), 203-213. https://doi.org/10.21831/jpa.v6i2.17707

Depdiknas. (2003). Undang-Undang Nomor 20 Tahun 2003 Tentang Sistem Pendidikan Nasional. Jakarta: Depdiknas, 33(20), 1-18.

Donnelly, P., Benson, J., \& Paul, K. (2012). How to Succeed at E-Learning. John Wiley \& Sons, Ltd. https:// doi.org/10.1002/9781118308455

Fauziddin, M., Mayasari, D., \& Rizki, L. M. (2021). Effective Learning for Early Childhood during Global Pandemic. Al-Ishlah: Jurnal Pendidikan, 13(1).

Febianti, Y. N. (2018). Peningkatan Motivasi Belajar dengan Pemberian Reward and Punishment yang Positif. Jurnal Edunomic, 6(2), 93-102. https://doi.org/10.33603/ejpe.v6i2.1445

Febrian, D. A. (2020). Asal Mula dan Penyebaran Virus Corona dari Wuhan ke Seluruh Dunia. In Idntimes.Com. https://bali.idntimes.com/health/medical/denny-adhietya/asalmuasal-dan-perjalanan-virus-corona-dari-wuhan-ke-seluruh-dunia-regional-bali/full

Harsasi, M. (2015). The use of open educational resources in online learning: A study of students' perception. Turkish Online Journal of Distance Education, 16(3), 74-87. https://doi.org/10.17718/tojde.46469

Imron, R. (2017). Hubungan Penggunaan Gadget dengan Perkembangan Sosial dan Emosional Anak Prasekolah di Kabupaten Lampung Selatan. XIII(2), 148-154. https://doi.org/10.26630/jkep.v13i2.922

Junus, I. S., Santoso, H. B., Isal, R. Y. K., \& Utomo, A. Y. (2015). Usability evaluation of the student centered e-Learning environment. International Review of Research in Open and Distance Learning, 16(4), 62-82. https:// doi.org/10.19173/irrodl.v16i4.2175

Kacetl, J., \& Semradova, I. (2020). Reflection on blended learning and e-learning - case study. Procedia Computer Science, 176, 1322-1327. https://doi.org/10.1016/j.procs.2020.09.141

Kemp, S. (2020). Digital 2020: Indonesia. https://datareportal.com/reports/digital-2020indonesia

Kepolisian Republik Indonesia. (2020). Maklumat Kepala Kepolisian Republik Indonesia Nomor Mak/2/III/2020 tentang Kepatuhan terhadap Kebijakan Pemerintah dalam Penanganan Virus Corona. 1(2), 1.

Peraturan Menteri Komunikasi dan Informatika Nomor 4 Tahun 2013 tanggal 14 Januari 2013, (2013).

Kumar Basak, S., Wotto, M., \& Bélanger, P. (2018). E-learning, M-learning and D-learning: Conceptual definition and comparative analysis. E-Learning and Digital Media, 15(4), 191-216. https:// doi.org/10.1177/2042753018785180

Kurniati, E., Nur Alfaeni, D. K., \& Andriani, F. (2020). Analisis Peran Orang Tua dalam Mendampingi Anak di Masa Pandemi Covid-19. Jurnal Obsesi : Jurnal Pendidikan Anak Usia Dini, 5(1), 241. https://doi.org/10.31004/obsesi.v5i1.541

Lilawati, A. (2020). Peran Orang Tua dalam Mendukung Kegiatan Pembelajaran di Rumah pada Masa Pandemi. Jurnal Obsesi : Jurnal Pendidikan Anak Usia Dini, 5(1), 549. https://doi.org/10.31004/obsesi.v5i1.630

M, S. (2017). The Impact of using Gadgets on Children. Journal of Depression and Anxiety, 07(01). https:// doi.org/10.4172/2167-1044.1000296

Maiza, Z., \& Nurhafizah, N. (2019). Pengembangan Keprofesian Berkelanjutan dalam Meningkatkan Profesionalisme Guru Pendidikan Anak Usia Dini. Jurnal Obsesi : Jurnal Pendidikan Anak Usia Dini, 3(2), 356. https://doi.org/10.31004/obsesi.v3i2.196

Surat Edaran Nomor 4 Tahun $2 \mathrm{O} 2 \mathrm{O}$ tentang Pelaksanaan Kebijakan Pendidikan dalam Masa Darurat Penyebaran Corona Virus Disease (COVID- 19), Menteri Pendidikan dan Kebudayaan Republik Indonesia 
https:// www.kemdikbud.go.id/main/blog/2020/03/se-mendikbud-pelaksanaankebijakan-pendidikan-dalam-masa-darurat-penyebaran-covid19

Mendikbud, R. I. (2020). Peraturan Menteri Pendidikan Dan Kebudayaan Republik Indonesia Nomor 3 Tahun 2020 Tentang Standar Nasional Pendidikan Tinggi. In Menteri Pendidikan dan Kebudayaan RI.

Nurdin, N., \& Anhusadar, L. (2020). Efektivitas Pembelajaran Online Pendidik PAUD di Tengah Pandemi Covid 19. Jurnal Obsesi : Jurnal Pendidikan Anak Usia Dini, 5(1), 686. https://doi.org/10.31004/obsesi.v5i1.699

Nurdyansyah, \& Fahyuni, E. F. (2016). Inovasi Model Pembelajaran. In Nizmania Learning Center. Nizamia Learning Center.

Nurkolis, N., \& Muhdi, M. (2020). Keefektivan Kebijakan E-Learning berbasis Sosial Media pada PAUD di Masa Pandemi Covid-19. Jurnal Obsesi : Jurnal Pendidikan Anak Usia Dini, 5(1), 212. https:// doi.org/10.31004/obsesi.v5i1.535

Nurul Fadlilah, A. (2021). Jurnal Obsesi: Jurnal Pendidikan Anak Usia Dini Strategi Menghidupkan Motivasi Belajar Anak Usia Dini Selama Pandemi COVID-19 melalui Publikasi. Jurnal Obsesi: Jurnal Pendidikan Anak Usia Dini, 5(1), 373-384. https:// doi.org/10.31004/obsesi.v5i1.548

Pranita, E. (2020). Diumumkan Awal Maret, Ahli: Virus Corona Masuk Januari. Kompas, 1.

Qwords. (2019). Data Jumlah Pengguna Internet di Indonesia Saat Ini. Qwords. https://qwords.com/blog/jumlah-pengguna-internet-di-

indonesia/\#: :text=Pengguna internet juga merangkul berbagai,usia 30 sampai 34 tahun.\&text=Dan usia diatas 65 tahun sudah mulai menurun.

Sahelatua, L. S., Victoria, L., \& Mislinawati. (2017). Kendala Guru Memanfaatkan Media It Dalam Pembelajaran Di Sdn 1 Pagar Air Aceh Besar. Journal of Chemical Information and Modeling, 53(9), 1689-1699.

Siswoyo, D., Sulistyono, T., Dardiri, A., Rohman, A., Hendrowibowo, L., \& Sidharto, S. (2013). Ilmu pendidikan. UNY Press.

Soekartawi. (2017). E-learning: Konsep dan Aplikasinya. In Paper presented in Balitbang Depdiknas Seminar ,18 Februari 2017 (Issue November). Universitas Pendidikan Ganesha.

Susilo, A., Rumende, C. M., Pitoyo, C. W., Santoso, W. D., Yulianti, M., Herikurniawan, H., Sinto, R., Singh, G., Nainggolan, L., Nelwan, E. J., Chen, L. K., Widhani, A., Wijaya, E., Wicaksana, B., Maksum, M., Annisa, F., Jasirwan, C. O. M., \& Yunihastuti, E. (2020). Coronavirus Disease 2019: Tinjauan Literatur Terkini. Jurnal Penyakit Dalam Indonesia, 7(1), 45. https://doi.org/10.7454/jpdi.v7i1.415

Tafqihan, Z. (2011). Karakteristik Dan Pemilihan Media Pembelajaran Dalam E-Learning. Cendekia: Jurnal Kependidikan Dan Kemasyarakatan, 9(2), 141-154.

Undang-Undang Dasar Negera Republik Indonesia 1945.

Wahyuningsih, D., \& Makmur, R. (2017). E-learning teori dan aplkasi. Informatika.

Wardani, A., \& Ayriza, Y. (2020). Analisis Kendala Orang Tua dalam Mendampingi Anak Belajar di Rumah Pada Masa Pandemi Covid-19. Jurnal Obsesi : Jurnal Pendidikan Anak Usia Dini, 5(1), 772. https:// doi.org/10.31004/obsesi.v5i1.705

Wulandari, H., \& Purwanta, E. (2020). Pencapaian Perkembangan Anak Usia Dini di Taman Kanak-kanak selama Pembelajaran Daring di Masa Pandemi Covid-19. Jurnal Obsesi : Jurnal Pendidikan Anak Usia Dini, 5(1), 452. https:// doi.org/10.31004/obsesi.v5i1.626

Yundatama, Y., \& Parno. (2015). E-Learning English for Children Aplikasi Mobile. Prosiding PESAT (Psikologi, Ekonomi, Sastra, Arsitektur \&Teknik Sipil), 6, 143-141.

Zakariyah, A., \& Hamid, A. (2020). Kolaborasi Peran Orang Tua dan Guru dalam Pembelajaran Pendidikan Agama Islam Berbasis Online di Rumah. Intizar, 26(1), 1726. https:// doi.org/10.19109/intizar.v26i1.5892

Zed, M. (2008). Metode Penelitian Kepustakaan. Yayasan Obor Indonesia. 